\title{
Test Results and A Recommended Test Procedure for Heat Traps
}

U.S. DEPARTMENT OF COMMERCE

National Bureau of Standards

National Engineering Laboratory

Center for Building Technoiogy

Buiiding Equipment Division

Washington, DC 20234

March 1984

Prepared for

U.S. Department of Energy

Washingron, DC 20585 

TEST RESULTS AND A RECOMMENDED TEST PROCEDURE FOR HEAT TRAPS

\section{James E. Harris}

U.S. DEPARTMENT OF COMMERCE

National Bureau of Standards

National Engineering Laboratory

Center for Building Technology

Building Equipment Division

Washington, DC 20234

March 1984

Prepared for

U.S. Department of Energy

Washington, DC 20585

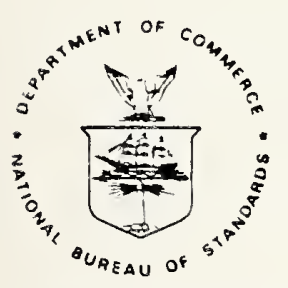

U.S. DEPARTMENT OF COMMERCE, Malcolm Baldrige, Secretary NATIONAL BUREAU OF STANDARDS, Ernest Ambler, Director 

A series of standby loss tests was conducted on a 40 gallon gas water heater to determine the magnitude and the variability of those losses. Tests were run with both inlet and outlet plugged and insulated to determine the jacket losses. Then tests were conducted with bare and insulated, vertical copper pipe, with and without heat traps. It was determined that the variability of the standby heat losses was of such a magnitude that the possible heat loss reduction by the use of heat traps could not be accurately detected and therefore the effectiveness of heat traps could not be accurately tested directly on gas water heaters. As a result of these findings a recommended test procedure for heat traps was developed using a water heater simulator and a number of tests conducted with four different heat traps in a variety of pipe sizes and material, bare and insulated, in vertical and horizontal orientations. It was recommended that the water heater simulator be used for any heat trap testing. It was also recommended that the heat trap credits currently given in the DOE water heater test procedure be dropped since any benefit of heat traps will be shown directly by the water heater test results.

Key words: appliances; energJ; heat traps; test procedures; testing; water heaters 


\section{NOMENCIATURE}

Cf Correction factor to convert the volume of gas to "Standard" Volume (Dimensionless)

Emf Direct Current Voltage (Volts)

Er Recovery efficiency (Dimensionless)

If Higher heating value of gas (Btu/SCF)

I Direct current (Amperes)

$J$ Water heater simulator heat loss factor (Watts/ $\mathrm{F}$ )

$k$ Specific heat of water ( 8.25 Btu/Gallon ${ }^{\circ} \mathrm{F}$ )

I Energy loss rate (Watts)

N Net heat loss factor (Watts/ F)

Pa Atmospheric pressure in inches of mercury (Note: if the pressure is in Millibars, then multiply by 0.02953 to convert to inches $\mathrm{Hg}$ )

Pg Gas pressure (inches Hg) (Note: to convert inches of water to inches $\mathrm{Hg}$, divide by 13.619)

Pwv Water vapor pressure, partial (inches Hg)

Q Volume of gas used at "Standard" conditions used during a test (Cubic feet)

S Standby loss, expressed as a decimal loss per hour $(1 / \mathrm{hr})$

SCP Standara cubic feet (Cubic feet)

QT3 The difference between the mean hot water temperature and the mean ambient air temperature, during a standby loss test (Twa-Taa) ( ${ }^{\circ} \mathrm{F}$ )

QT4 The difference between the initial mean tank temperature from the start to the end of a standby loss test ( $T f-T i)$ ( $F)$

Ta Ambient air temperature $\left({ }^{\circ} F\right)$

Taa Mean ambient air temperature during a standby loss test $\left({ }^{\circ} \bar{F}\right)$ 
Tf Mean tank temperature, final, at the end of a standby loss test ( $O F$ )

Mi Mean tank temperature, initial, at the start of a standby loss test ( $\circ \mathrm{F})$

Is Duration of a standby loss test (Hours)

Tw Mean tank water temperature at a particular time ( $\square$ )

Twa Mean tank water temperature during a standby loss test ( ${ }^{\circ} \mathrm{F}$ )

$\mathrm{V}$ Tank capacity (Galions)

W Power loss factor (Watts/ ${ }^{\circ} \mathrm{F}$ ) 


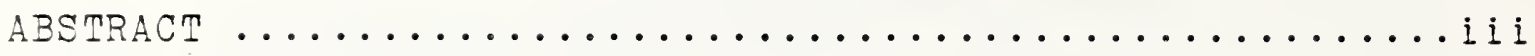

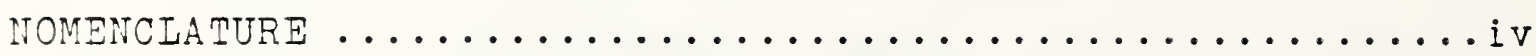

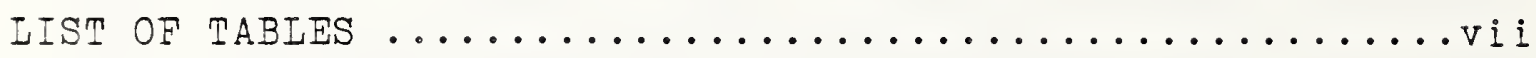
IIST OF FIGURES $\ldots \ldots \ldots \ldots \ldots \ldots \ldots \ldots \ldots \ldots \ldots \ldots \ldots \ldots \ldots \ldots$

1.0 INTRODUCTION $\ldots \ldots \ldots \ldots \ldots \ldots \ldots \ldots \ldots \ldots \ldots \ldots \ldots \ldots \ldots \ldots \ldots$

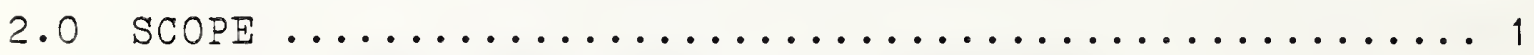

3.0 TEST PROCEDURES USED ON THE 40 GALION

GAS WATER HEATER . . . . . . . . . . . . . . . 2

3.1 TEST CONDITIONS AND INSTRUMENTATION USED WITH THE 40 GAILON GAS WATER HEATER .........

3.2 FACTORS AND EQUATIONS USED WITH THE 40 GALION GAS WATER HEATER TESTS .......... 6

3.2.1 CORRECTION FACTOR TO DETERMINE STANDARD GAS VOIUME USED ........6

3.2 .2 STANDBY IOSS DETERMINATION $\ldots \ldots \ldots \ldots 7$

3.2 .3 ENERGY LOSS RATE $\ldots \ldots \ldots \ldots \ldots \ldots$

3.2.4 SPECIFIC ENERGY IOSS RATE, IN WATMS PER DEGREE F $\ldots \ldots \ldots \ldots \ldots$

3.3 TEST RESULTS USING A 40 GALION

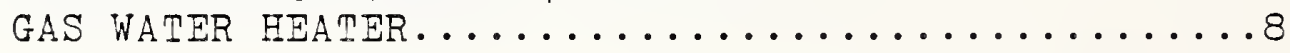

4.0 TEST CONDIMIONS AND INSTRUMENTATION USED WITH

GHE WATER HEATER SIMULATOR WITH VARIOUS HEAT

TRAPS AND PIPING ARRAIGEMENTS $\ldots \ldots \ldots \ldots \ldots \ldots \ldots$

4.1 FACTORS AND EQUATIONS USED WITH WATER HEATER STMULATOR .............. 13

4.1.1 WATER HEATER SIMUIATOR

HEAT LOSS FACTOR ............ 13

4.1 .2 NET HEAT IOSS FACTOR $\ldots \ldots \ldots \ldots \ldots \ldots$ 
4.2 TEST RESULTS USING THE WATER

HEATER SIMULATOR $\ldots \ldots \ldots \ldots \ldots \ldots \ldots \ldots \ldots \ldots \ldots \ldots \ldots$

5.0 TEST RESULTS COMPARED ................. 18

6.0 CONCLUSIONS $\ldots \ldots \ldots \ldots \ldots \ldots \ldots \ldots \ldots \ldots \ldots \ldots \ldots \ldots \ldots \ldots \ldots \ldots$

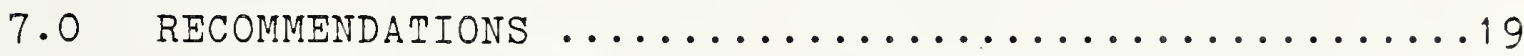

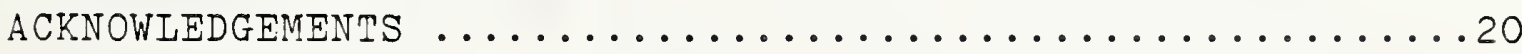

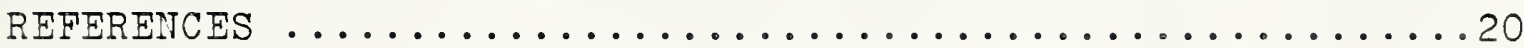

LIST OF TABLES

Table 1. Summary of Heat Trap Tests Conducted on a 40 Galion, Foam-Insulated Gas Water Heater...... 3

Table 2. Test Results on a 40 Gallon, Foam-Insulated,

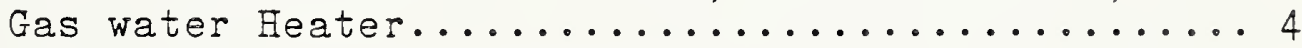

Table 3. Summary of Net Heat Loss Factors..............10 Table 4. Units Conversion Table: SI/INCH-POUND/SI.......24

\section{LIST OF FIGURES}

Figure 1. Gas Water Heater Test Setup.................. 3

Figure 2. Check Valve Type Heat Traps

(For Use on Hot Water and Cold Water) type "C"... 5

Figure 3. Heat Traps Used on Hot Water Outlet OnIy

Types: "A", "B" and "D".................. 5

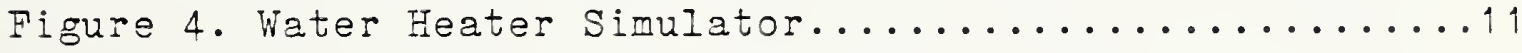

Figure 5. Water Heater Simulator AssembIy............... 12

Figure 6. Net Heat Loss Eactors, N (With Bare Pipes.).....14

Figure 7. Net Feat Loss Factors, N

(AII With Insulated Pipes) ................ 15

Figure 8. All Tests in Ranked Order of

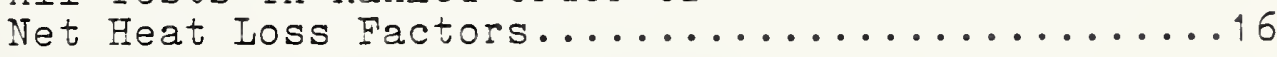





\subsection{INTRODUCTION}

Currently there are no established Department of Energy (DOE) test procedures for heat traps. As used in this report, a heat trap is a device which can be integrally connected, or independently attached, to the hot or cold water pipe connections of a water heater storage tank such that the device will develop a thermal or mechanical seal to minimize the recirculation of water due to natural thermal convection between the water heater tank and its water supply pipes and thereby reduce the heat loss to the environment from the hot water stored in the water heater. [1]

Tests of heat traps have been conducted at the National Bureau of Standards (NBS) using gas water heaters and simulated electric water heaters. The results of heat trap tests using the simulated electric water heater were originally reported in reference [2]. Concern had been expressed [3] that heat traps should be tested on gas water heaters since gas water heaters have convective air currents that are induced by the combustion and the flue currents. It was suspected that these air currents would be sufficiently greater than those air currents that might be induced about an electric water heater. It was surmised that these increased air currents about a gas water heater may cause different performance of heat traps than when the same heat traps were used with electric water heaters.

The objective of this study was to determine whether heat traps could be tested with sufficient accuracy to determine their effectiveness and if so to establish a uniform test method.

\section{O SCOPE}

The first phase of this effort was conducted on a 40 gallon gas water heater using commercially available check valve type heat traps (Type "C"). These heat traps were tested using the test configuration as shown in figure 1 and are detailed in figure 2 .

The second phase of this effort used four different heat traos (see figures 2 and 3. ) and were tested using the water heater simulator (see figures 4 and 5 ). 


\subsection{HEAT TRAP DESCRIPTIONS}

Four (4) types of heat traps were used for this study. They are:

2.1.1 Type "A" (See figure 3) was a brass 3/4" pipe of a "pigtail" design with a 270 degree turn; it was obtained from a mail order retailer.

2.1.2 Type "B" (See figure 3) was a 3/4" brass check valve with female pipe threads on both ends. This was a commercially available check valve and was not specifically designed as a heat trap. This check valve had a hemispherically-shaped plastic plug and was modified to prevent full closure by the insertion of an 0.008 " diameter wire between the plug and the seat to prevent the build-up of dangerous internal pressures.

2.1.3 Type "C" (See figure 2) was a commercially available patented check valve type heat trap (U. S. Patent No. $4,083,583$ ) of $3 / 4 "$ copper with $3 / 4 "$ male pipe threads on both ends and a plastic cage liner and a plastic ball for the moveable plug in the check valve. This type had a controlled leakage in the reverse direction of flow to prevent a dangerous pressure build-up within the water heater tank.

2.1.4 Type "D" (See figure 3) was a 1/2" copper pipe with $3 / 4 "$ pipe threads-to-copper pipe adapters on each end with a 3/4" brass street elbow. This type is a piping configuration that may represent one of the many possible types of heat traps that may be fabricated using standard pipe fittings and pipe.

The type "C" heat trap was the only heat trap used in conjunction with the 40 gallon gas water heater tests.

3.0 TEST PROCEDURES USED ON THE 40 GAIION GAS WATER HEATER

The test setup used for the 40 gallon gas water heater is shown in figure 1.

To determine if the heat loss reduction by the use of heat traps could be accurately detected directly on a typical gas water heater, tests were run on a 40 gallon gas water heater. The following tests (see table 1.) were run:

3.0.1. Water heater test with the inlet and outlets plugged and insulated. This test was a standby loss test using the procedures in [4] and was the basis for 
TABLE 1.

HEAT TRAP TESTS CONDUCTED ON A 40 GAL. FOAM-INSULATED GAS WATER HEATER

\begin{tabular}{|c|c|c|c|c|}
\hline $\mathrm{L}$ (Watts) & $\begin{array}{l}\text { Spread* } \\
\text { (Watts) }\end{array}$ & $\begin{array}{c}\text { Mean } \\
\text { Watts } /{ }^{\circ} \mathrm{F}\end{array}$ & $\begin{array}{c}\text { Spread } \\
\text { Watts } /{ }^{\circ} \mathrm{F}\end{array}$ & TYPE OF TEST CONDITIOIS \\
\hline 333.12 & 47.50 & 4.508 & 0.639 & Plugged \& insulated \\
\hline 359.90 & 78.37 & 4.728 & 0.954 & Bare,vertical, no heat traps \\
\hline 395.33 & 14.44 & 5.141 & 0.137 & Insulated,vertical. no heat traps \\
\hline 274.52 & 13.54 & 3.895 & .0 .000 & Bare, vertical, with heat traps $\stackrel{*}{*}$ \\
\hline 33$\} .55$ & 77.70 & 4.573 & 1.033 & Insulated, vertical, with heat traps $\stackrel{*}{*}$ \\
\hline 341.396 & 46.31 & 4.596 & 0.553 & MEAN OF ALL TESTS \\
\hline
\end{tabular}

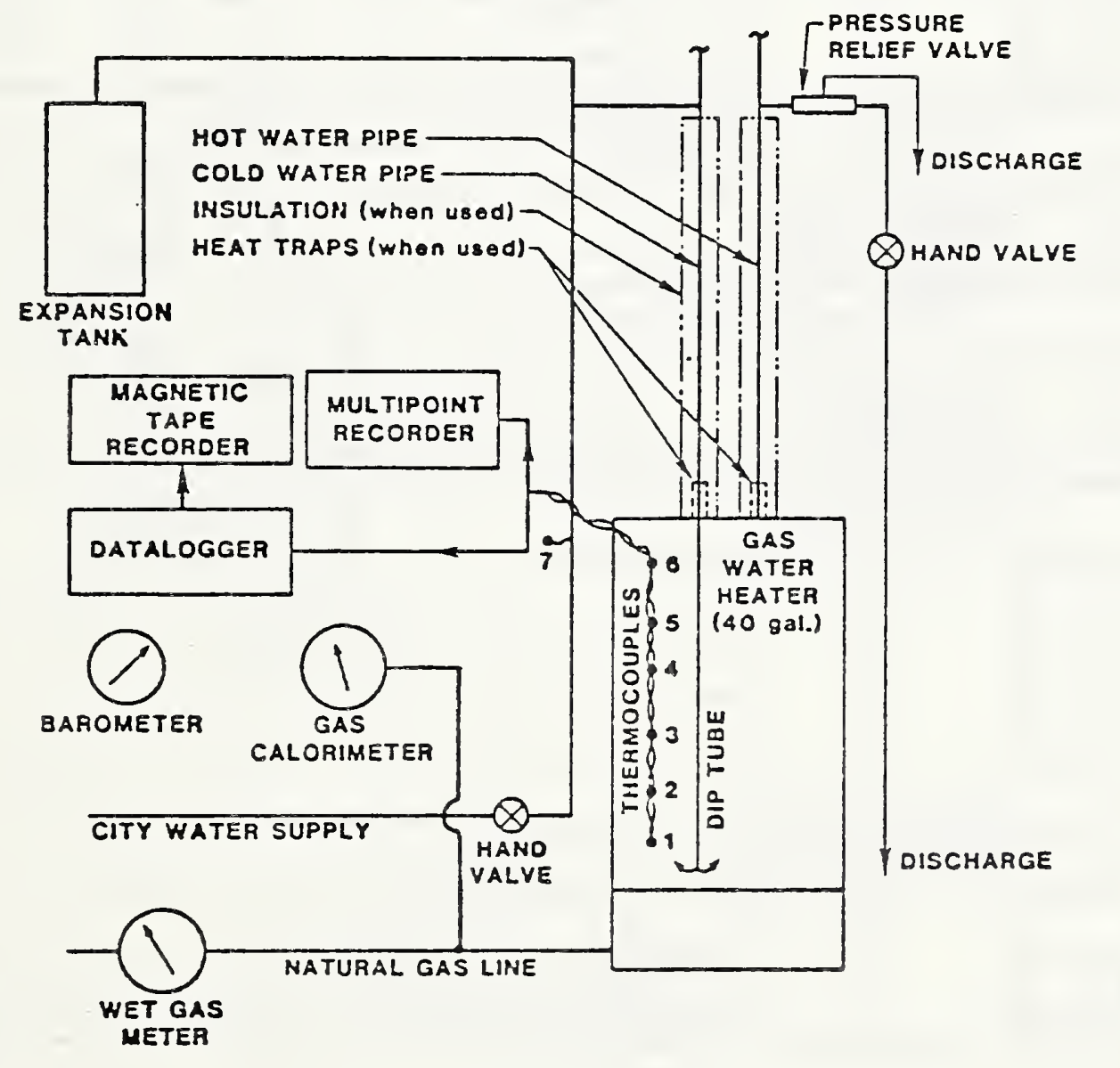


TABLE 2.

TEST RESULTS ON A 40 GALLON, FOAM-INSULATED GAS WATER HEATER

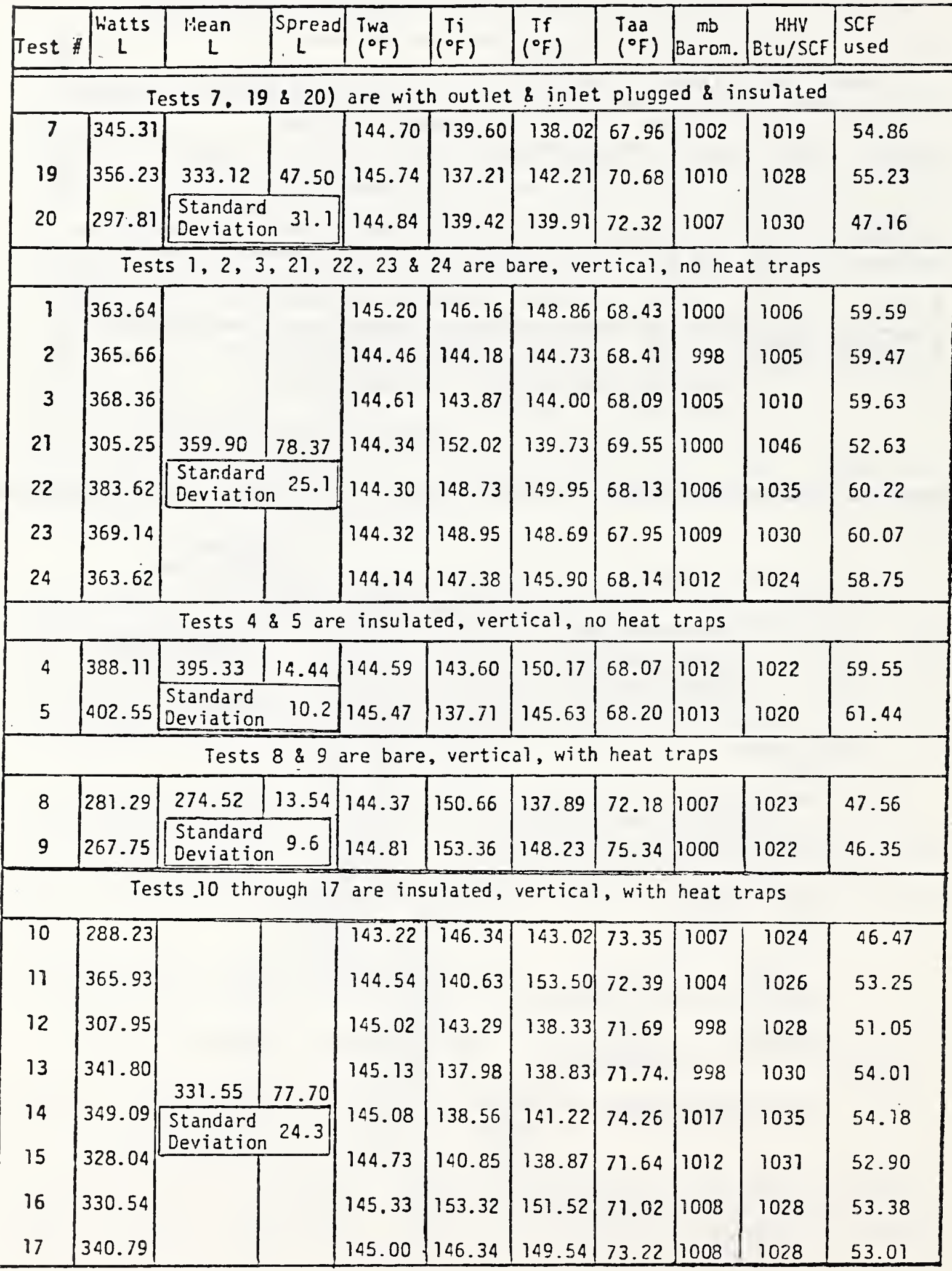


determining the jacket losses. There were no pipe or heat trap Iosses since the inlet and outlets were plugged and insulated.

3.0.2. With bare, vertical, 3/4" copper pipes to the hot water outlet and cold water inlet, whithout any heat traps. This is considered to be a typical household installation.

3.0.3. With insulated, vertical, 3/4" copper pipes to the hot water outlet and cold water inlet, without any heat traps.

3.0.4. With bare, vertical, 3/4" copper pipe and heat traps (type "C") on both the hot water outlet and the cold water inlet.

3.0.5. With insulated, vertical, 3/4" copper pipe and with heat traps (type "C") on both the hot water outlet and the cold water inlet.

3.1 TEST CONDITIONS AND INSTRUMENTATION USED WITH THE 40 GALION GAS WATER HEATER

The test procedures, test conditions and instrumentation requirements specified in reference [4] were used in this investigation. The test setup used for the 40 gallon gas water heater tests is shown in figure 1. The tests conducted on the gas water heater were all standby loss tests specified in paragraphs 3.4 .1 to 3.6 of reference [4].

3.2 FACTORS AND EQUATIONS USED WITH THE 40 GAIION GAS WATER HEATER TESTS

The following factors and equations were used to determine the volume of gas used at standard conditions, standiy Ioss energy loss rate and the specific energy loss rate in watts per degree $\mathrm{F}^{*}$ :

3.2.1 CORRECTION FACTOR TO DETERMINE STANDARD GAS VOIUME USED

The correction factor, Cf, to determine the "Standard" gas volume used was determined using equation (1) where "Standard" conditions are at $60^{\circ} \mathrm{F}$ and 30.00 inches Hg

*NOTE: Fahrenheit degrees and Btu units are used in this report to be consistent with DOE and other published and proposed test procedures for water heaters. A conversion table for SI units is included in mable 4, on page 21. 
(1016 millibars) atmospheric pressure. The partial pressure of the water vapor was determined from tables of vapor

pressure of water at various temperatures, by entering the appropriate gas temperature. The other pressures were taken from appropriate instrument readings. The Cf is used as a multiplier in the product of measured gas (cubic feet) to yield standard cubic feet (Q) of gas used in equation (2).

The correction factor, Cf, (dimensionless) to determine standard gas volume used during a gas water heater standby loss test and is defined as:

$$
\begin{aligned}
\mathrm{Cf}=(17.64)(\mathrm{Pg}+\mathrm{Pa}-\mathrm{PwV}) /(\mathrm{Tg}+460) \\
\text { Where: } \mathrm{Pg}=\text { Gas pressure (inches } \mathrm{Hg}) \\
\mathrm{Pa}=\text { Atmospheric pressure (inches } \mathrm{Hg}) \\
\mathrm{PwV}=\text { Water vapor pressure, partial, (inches Hg) } \\
\mathrm{Tg}=\text { Temperature of gas ( } \circ \mathrm{F})
\end{aligned}
$$

\subsubsection{STANDBY LOSS DETERMINATION}

The standby loss, $S$, was determined using the test procedure in reference[4] and equation (2). The second term corrects for any energy difference between the mean tank temperature at the start of a test and that at the end of a test. The standby loss is expressed as a decimal loss per hour and is subsequently used in equation (3) to determine the average energy loss rate.

Standby loss is the ratio of the amount of energy lost per hour to the available energy above the datum of the average ambient air temperature and is defined as:

$$
S=(Q)(E) /((k)(V)(\Delta T 3)(T s))-(\Delta T 4) /((\Delta T 3)(T s)(E r))
$$

Where: $Q=$ Standard cubic feet of gas used during the standby loss test (Cubic feet)

$$
\begin{aligned}
H= & \text { The higher heating value of the gas used } \\
& \text { (Btu/Standard cubic foot) } \\
k= & \text { Specific heat of water ( } 8.25 \mathrm{Btu} /(\text { gal. F })) \\
V= & \text { Tank capacity (Gallons) }
\end{aligned}
$$




$$
\begin{aligned}
\Delta \mathrm{TZ}= & \text { The difference in the mean water temperature } \\
& \text { during the standby loss test and the mean } \\
& \text { ambient air temperature during the standby } \\
& \text { loss test, (Twa-Taa) ( } \left.{ }^{\circ} \mathrm{F}\right) \\
\Delta \mathrm{T} 4= & \text { The difference in the mean water temperature } \\
& \text { at the end of the standby loss test and the } \\
& \text { mean water temperature at the beginning of } \\
& \text { the standby loss test, (Tf-Ti) ( } \left.{ }^{\circ} \mathrm{F}\right) . \\
\mathrm{Ts}= & \text { The duration of the standby loss test (Hours) } \\
\mathrm{Er}= & \text { Recovery efficiency as determined by } \\
& \text { paragraph } 4.1 .1 \text { of [4] (Dimensionless) }
\end{aligned}
$$

\subsubsection{ENERGY IOSS RATE}

The hourly standby loss, $S$, as determined by equation (2) is used to determine the energy loss rate, in watts, and is defined as:

$$
I=(S)(V)(\Delta T 3)(k)(1 / 3.412)
$$

Where:S, V, $\triangle T 3$, and $k$ are defined in paragraph 3.2.2. 3.2.4 SPECIFIC ENERGY LOSS RATE, IN WATTS PER DEGREE F The specific energy loss rate, $W$, expressed in watts per degree Fahrenheit is calculated by equation (4) using the energy loss rate determined by equation ( 3 ).

Specific energy loss rate, in watts per degree $F$ is the measure of heat loss at a specific mean water temperature above the mean ambient air temperature and is defined as:

$$
W=(I) /(\Delta T 3)
$$

Where: $I$ is defined in paragraph 3.2 .3 and $\Delta T 3$ is defined in paragraph 3.2 .2 .

\subsection{TEST RESULTS USING A 40 GAIION GAS WATER HEATER}

Table 1 shows the summary of the test results of the heat trap tests conducted on a 40 gallon, foam-insulated, gas water heater. For this series of tests, all tests were conducted using only the more commonly used $3 / 4 "$ copper pipe and all pipe runs were vertically oriented. These tests were with and without piping insulation, with and without heat 
traps (OnIJ type "C" heat traps were used on these tests). When heat traps were used, they were used on both the hot water outlet and the cold water inlet.

The tests with the cold water inlet and hot water outlet plugged and insulated was used as the base for the heat loss of the gas water heater. The other heat losses with the other configurations were compared to this base heat loss and the effectiveness of the heat traps and piping configuration was determined by making a comparison to the base heat loss.

These tests were repeated a number of times in order to determine the variation (spread) and the standard deviation of the test results. These data are presented in Table 2. The bottom Iine of Table 1 is a mean of all tests with the 40 gallon gas water heater. Of special interest is the EnergJ Loss Rate, I, in Watts; the spread of this loss rate, I, and the mean Specific Enerey Loss Rate, W, in Watts per degree F; and the spread of the Specific Energy Loss Rate. It can be seen that the mean of the spread of the Specific EnergJ Loss Rate is 0.553 Watts per degree F. This means that for a $90^{\circ} \mathrm{F}$ rise of the hot water temperature above the ambient air temcerature, there would be a 49.77 watts (4,076 Btu/daJ) spread in the energJ loss rate. The credit given for heat traes by [4] is the equivalent of 16 watts on the hot water outiet and 12 watts on the cold water inlet; a total of 28 watts. Therefore, in these tests the mean of the soread of the Soecific Energy Loss Rate $\left(0.553 \mathrm{~W} /{ }^{\circ} \mathrm{F}\right)$ results in a soread of 49.77 watts, which is $178 \%$ of the heat trap credit ( 28 watts). Since this spread and variation of the test results is excessive, a more meaningful and accurate test method than direct testing on a water heater is needed. The needed test method was believed to be a smaller water heater which woula have smaller standby losses and hence sualler spread of these heat losses. The smaller water heater used was the Huter heatar simulator, described in figures 4 and 5 .

4.0 TEST CONDITIONS AND INSTRUMENTATION USED WITY TEE WATER LEATER SIMUEATOR WITH VARIOUS HEAT TRAPS AND PIPING ARRANGEMENTS

Tests were also conducted on four different heat trap designs (Figures 2 and 3 and paragraph 2.1) using the electric water heater simulator (Figures 4 and 5). The water heater simulator was designed and used for the various heat traps and piping configurations tested; the results are shown in Table 3. Tests were conducted using bare pipes (of $1 / 2^{\prime \prime}$ copoer pipe, 3/4" copper pipe and 3/4" galvanized steeI pipe), with and without heat traps, in both the horizontal and vertical pipe orientations. Tests were also conducted 
TABLE 3.

SLMBARY OF NET HEAT LOSS FACTORS, N. (1)

(WITH VARIOUS PIPE SIZES, MATERIALS, ORIENTATION;

BARE AND INSULATED, WITH VARIOUS HEAT TRAPS AND WITH NO HEAT TRAPS)

TESTED WITH THE WATER HEATER SIMULATOR

\begin{tabular}{|c|c|c|c|c|c|c|c|c|c|c|}
\hline \multirow{3}{*}{$\begin{array}{l}\text { Plpe Type } \\
\text { Material and } \\
\text { Orlentation }\end{array}$} & \multicolumn{10}{|c|}{ Heat Trap Type Used for Test (4) } \\
\hline & \multicolumn{5}{|c|}{ Bare P1pe Runs } & \multicolumn{5}{|c|}{ Insulated P1pe Runs } \\
\hline & None & $" A "$ & $" B "$ & $" \mathrm{C} "$ & ${ }^{\prime \prime}{ }^{-}$ & ${ }^{\prime} A^{-}$ & $" B{ }^{\prime \prime}$ & ${ }^{*} \mathrm{C}^{-}$ & ${ }^{*} D^{-}$ & None \\
\hline \multirow{2}{*}{$\begin{array}{l}5^{\prime} \times 1 / 2^{\circ} \mathrm{Cu} \\
\text { Vertical }\end{array}$} & 0.102 & 0.041 & 0.090 & $\begin{array}{c}(2) \\
X\end{array}$ & 0.072 & $\mathrm{x}$ & 0.050 & 0.072 & 0.054 & 0.076 \\
\hline & 9.20 & 3.65 & 8.10 & & 6.50 & & 4.50 & 6.50 & 4.85 & 6.80 \\
\hline \multirow{2}{*}{$\begin{array}{l}5^{\prime} \times 3 / 4^{\circ} \mathrm{Cu} \\
\text { Vert1 cal }\end{array}$} & 0.192 & 0.096 & 0.091 & 0.144 & 0.113 & 0.046 & 0.086 & 0.104 & 0.066 & $0.14:$ \\
\hline & 17.25 & 8.65 & 8.15 & 13.00 & 10.15 & 4.10 & 7.75 & 9.35 & 5.95 & 12.90 \\
\hline \multirow{2}{*}{$\begin{array}{l}5^{\prime} \times 3 / 4^{\circ} \\
\text { Galvanized } \\
\text { Steel (3) } \\
\text { Vertical }\end{array}$} & 0.204 & $\mathrm{x}$ & $\mathrm{x}$ & $\mathrm{x}$ & $\mathrm{X}$ & $x$ & $\mathrm{X}$ & $x$ & $x$ & 0.142 \\
\hline & 18.35 & & & & & & & & & 12.75 \\
\hline \multirow{2}{*}{$\begin{array}{l}5^{\prime} \times 1 / 2^{-} \mathrm{Cu} \\
\text { Hor1zontal }\end{array}$} & $X$ & 0.037 & 0.055 & $\mathrm{X}$ & $\mathrm{X}$ & $x$ & 0.033 & 0.033 & $\mathrm{x}$ & $\mathrm{X}$ \\
\hline & & 3.35 & 4.95 & & & & 2.95 & 2.95 & & \\
\hline \multirow{2}{*}{$\begin{array}{l}5^{\prime} \times 3 / 4^{\prime} \mathrm{Cu} \\
\text { Horizontal }\end{array}$} & 0.307 & 0.089 & 0.119 & 0.057 & 0.084 & 0.058 & 0.131 & 0.059 & 0.042 & 0.186 \\
\hline & 27.65 & 8.00 & 10.75 & 5.10 & 7.55 & 5.20 & 11.75 & 5.30 & 3.80 & 16.70 \\
\hline \multirow{2}{*}{$\begin{array}{l}5^{\prime} \times 3 / 4^{\circ} \\
\text { Galvanized } \\
\text { Steel } \\
\text { Horlzontal }\end{array}$} & 0.398 & $\mathrm{X}$ & $x$ & $\mathrm{X}$ & $\mathrm{X}$ & $x$ & $\mathrm{X}$ & $x$ & $\mathrm{X}$ & 0.247 \\
\hline & 35.85 & & & & & & & & & 22.50 \\
\hline
\end{tabular}

Notes: (1) Units of Net Heat Loss Factors, $N$, are Watts/degree Fahrenheit. The bottom figures are hatts, based upon a $90^{\circ} \mathrm{F}$ rise.

(2) $X$ denotes no test conducted.

(3) The data shown for the pipe only was for comparison of previous work in [5] with copper pipe used here.

(4) HEAT TRAP TYPES: (See Figures 2 \& 3 for pictorial description)

"A" - Brass $3 / 4^{\prime \prime}, 270^{\circ}$ turn, from ma1l order retaller

" $B "-3 / 4^{\prime \prime}$ Brass Check Valve (Controlled leak in reverse direction)

"C" - Patented ball check valve type, 3/4"

" $D$ " Fabrication from pipe and elbows 


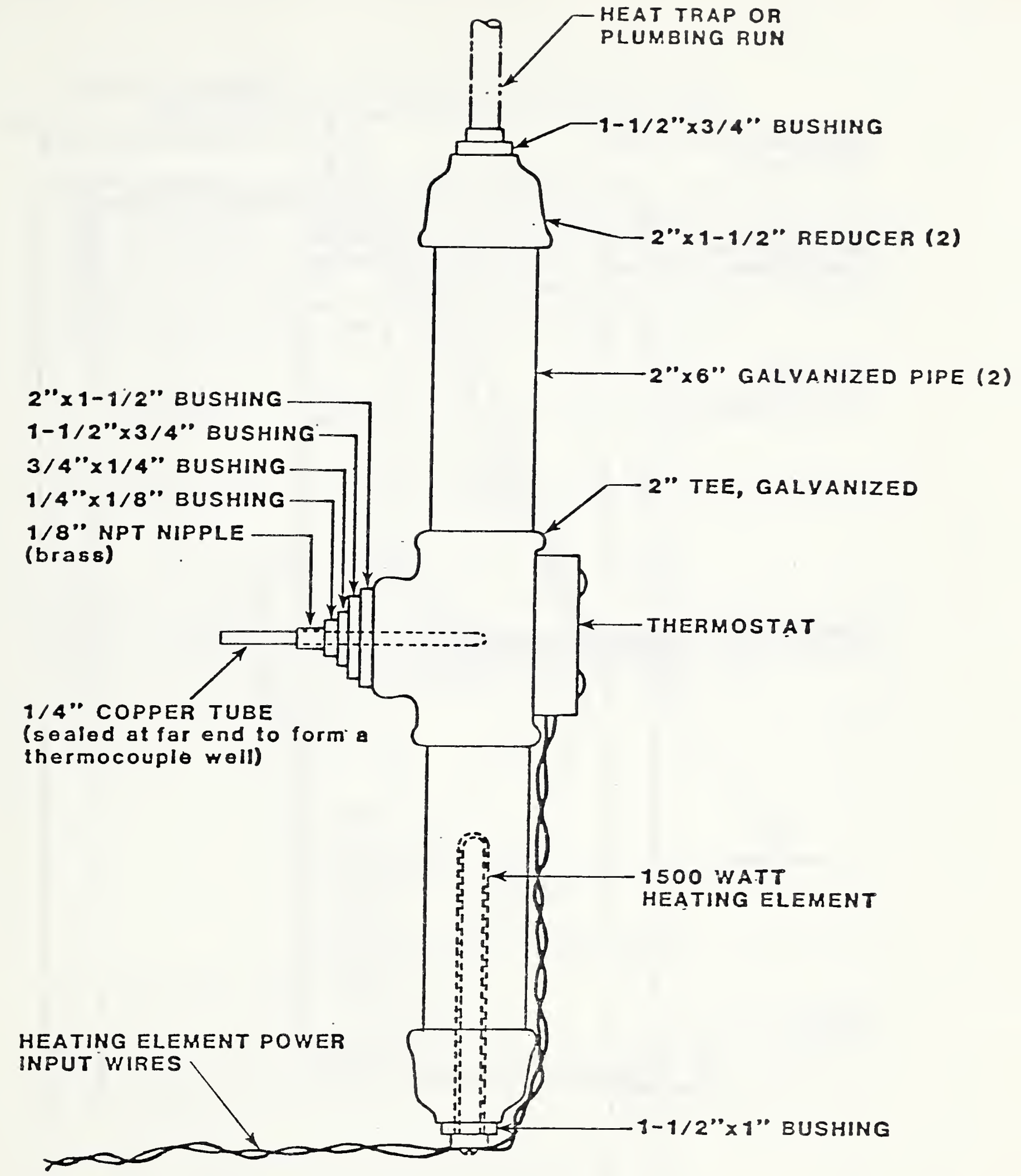

WATER HEATER SIMULATOR

FIGURE 4. 


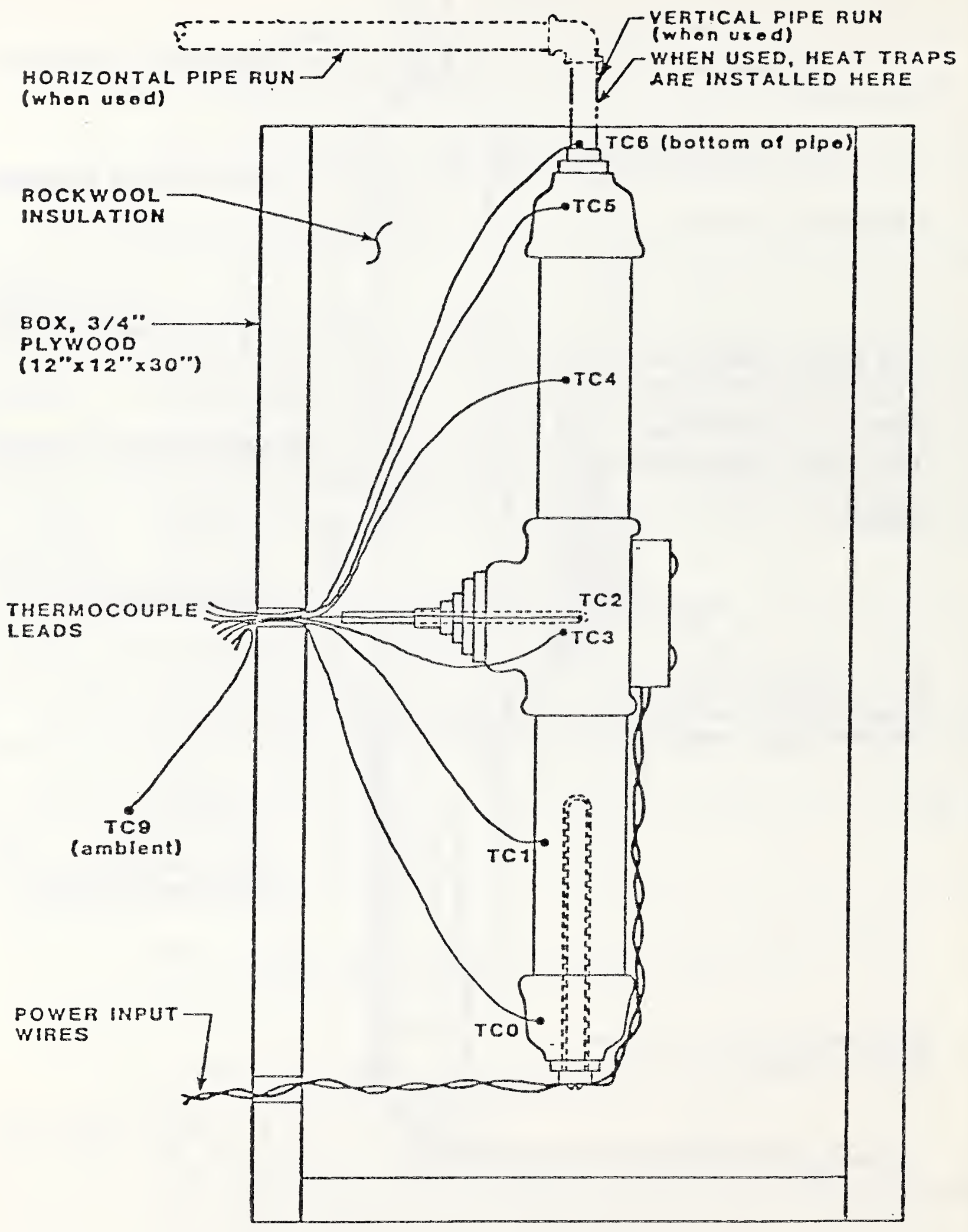

WATER HEATER SIMULATOR ASSEMBLY

FIGURE 5. 
with insulated pipes (of 1/2" copper, 3/4" copper and 3/4" galvanized steel) with and without heat traps in the vertical and horizontal orientations. In all tests with the water heater simulator assembly (figure 5), the tests were run Iong enough to ensure that thermal equilibrium had been achieved; this was verified by the multipoint recorder trace. These test data were used as a basis for measuring the effectiveness of heat traps.

\subsection{FACTORS AND EQUATIONS USED WITH MHE WATER HEATER} SIMULATOR

The following factors and equations were used to determine the water heater simulator heat loss factor and the net heat loss factor.

\subsubsection{WATER HEATER SIMULATOR HEAT LOSS FACTOR}

The water heater simulator loss factor, $J$, expressed in watts per degree Fahrenheit, is the energy loss rate of the water heater simulator assembly, packaged as shown in figure 5 , without any piping or heat traps and is defined as:

$$
J=(\operatorname{Emf})(I) /(T w-T a)
$$

Where: Emf $=$ dc volts

$$
\begin{aligned}
I= & d c \text { amperes } \\
\mathrm{T}_{\mathrm{w}=} & \text { Water temperature using thermocouple } \mathrm{TC2}, \\
& \text { expressed in degrees } \mathrm{F} \\
\mathrm{Ta}= & \text { Ambient air temperature, using thermocouple } \\
& \mathrm{TC}, \text { expressed in degrees } \mathrm{F}
\end{aligned}
$$

\subsubsection{NET HEAT IOSS FACTOR}

The net heat loss factor, $N$, expressed in watts per degree Fahrenheit, is the piping/heat trap configuration heat loss after allowing for the electric water heater simulator heat losses and is defined as:

$$
N=((\operatorname{Em} \hat{f})(I)-(J)(T w-T a)) /\left(T_{w}-T a\right)
$$

Where: Emf, I, Tw, Ta, and $J$ are defined in para. 4.1 .1

It can be seen that the second term in the numerator of equation (6) accounts for the power loss due to the water heater simulator only, and that the net value of the numerator is the rate of energy loss (in watts) due to the 


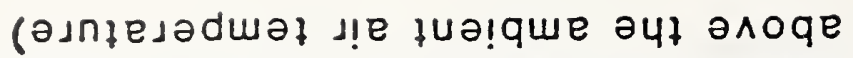

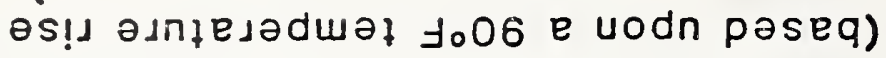

$S \perp \perp \forall M$ ' $\exists \perp \forall$ SSO $\perp \forall \exists H$

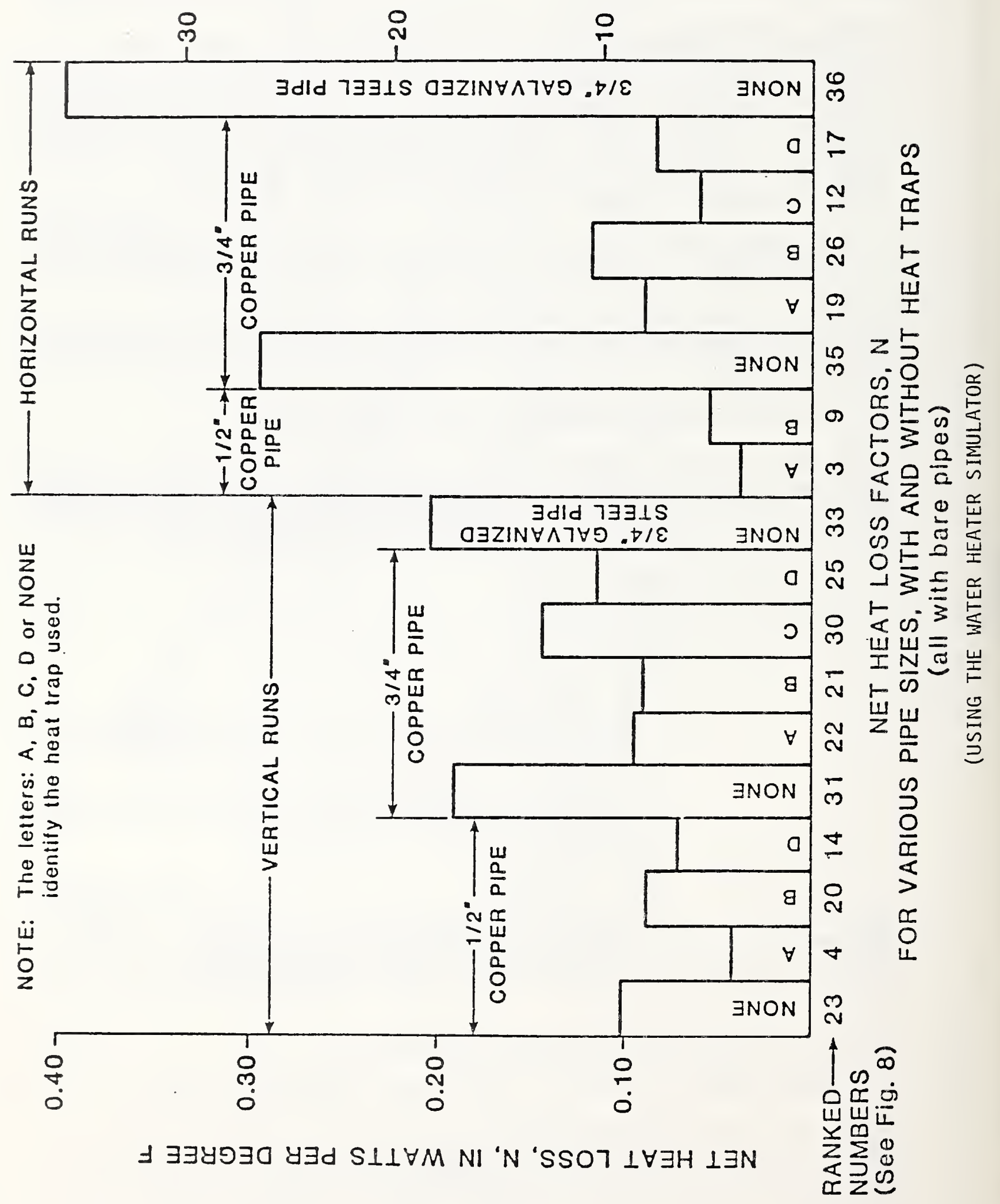


(әлnjeladuəł as!l asniesadwał 」o06 e uodn paseq)

$S \perp \perp \forall M ' \exists \perp \forall Y$ SSO $\perp \forall \exists H$

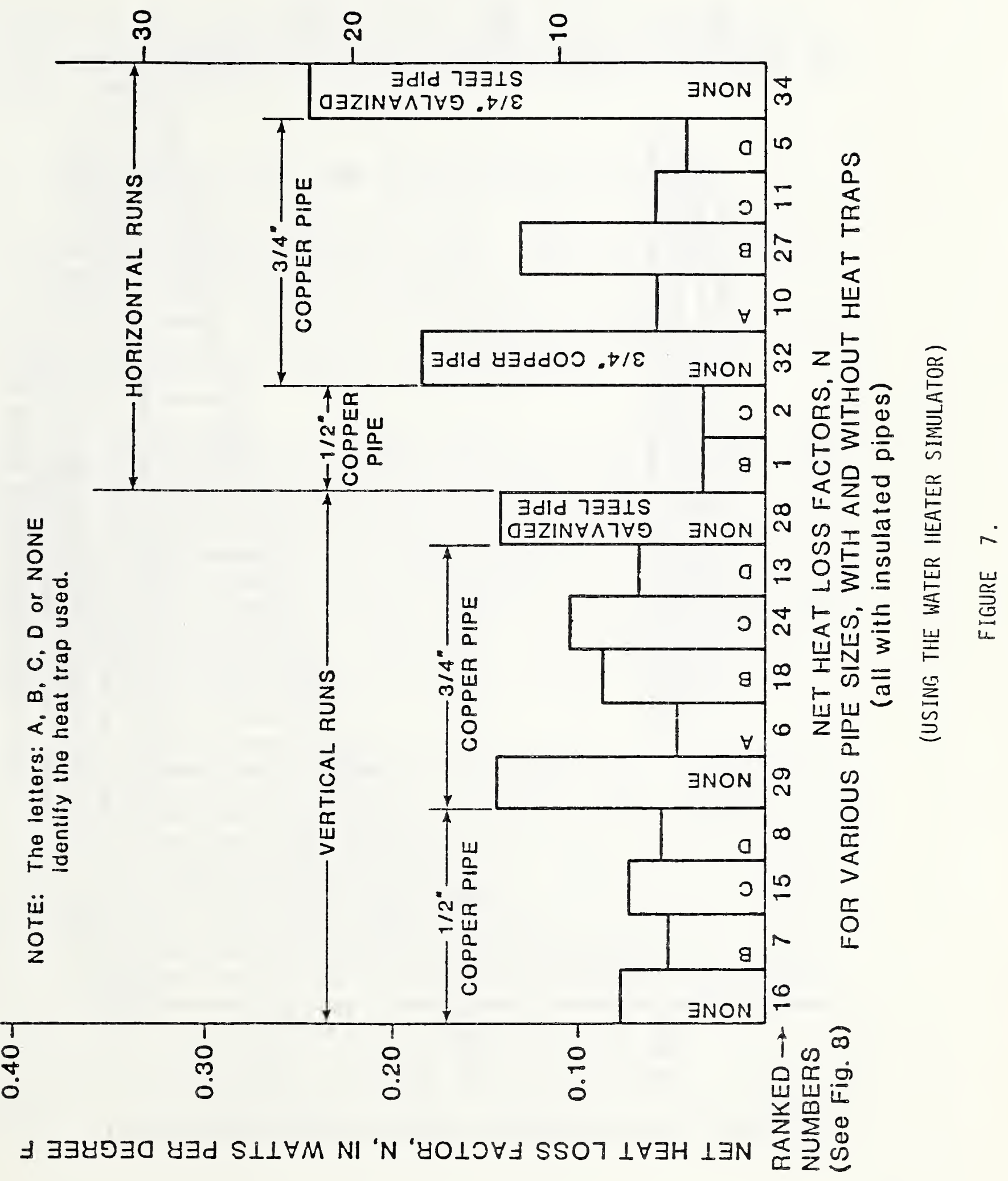




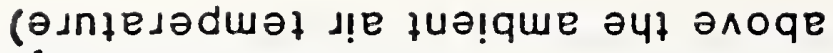
әs!

$S \perp \perp \forall M ' \exists \perp \forall Y$ SSO $\perp \forall \exists H$

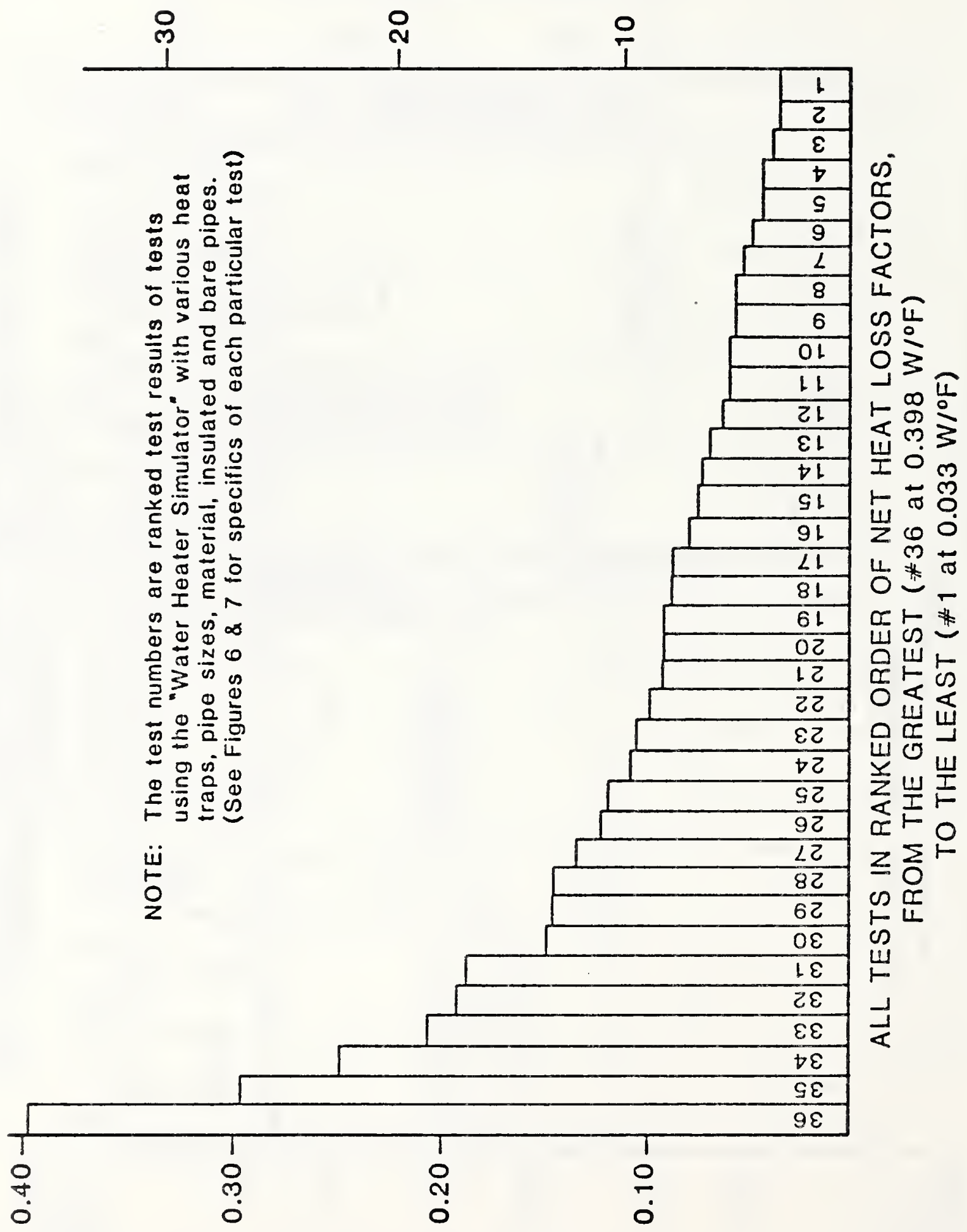

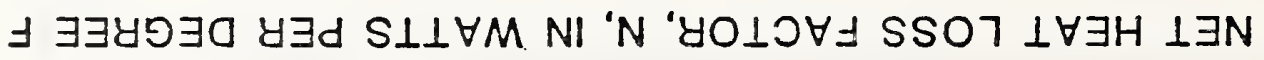


added piping. This net value divided by the temperature difference between the water temperature and the ambient air temperature yields the Net Heat Loss Factor, $N$, in watts per degree Fahrenheit.

\subsection{TEST RESULTS USING THE WATER HEATER SIMULATOR}

Test results of all tests conducted using the water heater simulator with all combinations of: pipe size, material, orientation, insulation, with heat traps (of various types) and without heat traps are summarized in table 3. The results are shown graphically in Figures 6 and 7 . In Figure 8 the test results are shown in descending order of heat loss rates (in watts per degree $F$ and in watts).

It is believed that 3/4" copper pipe is the most common water heater inlet and outlet piping used, followed by 1/2" copper pipe; 3/4" galvanized (or black finished) steel pipe is seldom used [6]. The galvanized steel pipe was tested to compare the results with Pierson's prior work [5]. Pierson reported the equivalent Net Heat Loss Factor, $N$, of:

"greater than 0.178 Watts per degree F". A comparable test in this report (ranked as \#33) resulted in a value of 0.204 Watts per degree $F$. Test results for the commonly used piping size and material, 3/4" bare, vertical copper pipe, without heat traps (test \#31 in this report) resulted in a Net Feat Loss Factor of 0.192 Watts per degree F.

All heat traps tested with the water heater simulator were tested with bare and insulated pipe runs, with vertical and horizontal pipe runs, with $1 / 2^{\prime \prime}$ and $3 / 4^{\prime \prime}$ copper pipe. The 3/4" galvanized steel was tested with bare and insulated pipe runs, with vertical and horizontal pipe runs, without heat traps. The type "B" and type "C" heat traps were virtually equivalent with 1/2" copper, insulated pipe in a horizontal orientation at a Net Heat Loss Factor, $\bar{N}$, of 0.0326 Watts per degree $F$ and 0.0327 Watts per degree $F$, respectively and by rounding to three significant figures, they were equivalent at $0.033 \mathrm{~W} / \mathrm{F}$. This is not too surprising since they were essentially the same type of heat trap, namely, a modified check valve. The pipe with the greatest heat loss rate was bare, 3/4" galvanized steel pipe, without any heat traps, oriented horizontally. This Net Heat Loss Factor, $N$, was $0.398 \mathrm{~W} / \mathrm{F}$ or 35.8 watts at a $90^{\circ} \mathrm{F}$ temperature rise above the ambient air temperature. 
It can be seen from the data in Table 3 and Figures 6 and 7 , that there is no consistent pattern of heat losses in the vertical as compared to the horizontal piping orientation with the three different piping materials and sizes (1/2" \& 3/4" copper and 3/4"galvanized steel) tested.

For the heat trap tests using the water heater simulator, tests were run only to simulate the hot water outlet: No attempt was made to test the heat traps on the cold water inlet (with the water heater simulator) because of the complications due to the variety of dip tube configurations that may be encountered in the various water heaters in use.

\subsection{TEST RESULTS COMPARED}

A mean of seven tests of the water heater simulator showed a heat loss rate of 8.75 watts with a $90^{\circ} \mathrm{F}$ temperature rise above the ambient air temperature. The spread of these seven tests was 0.325 watts. This was the heat loss of only the water heater simulator without any piping. When this spread of heat loss is compared with the spread of the heat loss on seven tests of the 40 gallon gas water heater, with bare, vertical 3/4" copper pipes without heat traps the ratio is $0.325 / 78.37$ (which is 0.004147 ). (The inverse of this ratio is 241.1 to one). The statistical analysis of the seven tests with the water heater simulator showed a standard deviation of 0.132 watt loss rate with a $90 \mathrm{~F}$ rise above the ambient air temperature. When the standard deviations of the above same tests are compared, the results are the ratio of $0.132 / 25.057$ (which is 0.005268 ). (The inverse of this ratio is 189.8 to one). It can be seen that this spread of 78.37 watts heat loss rate of the 40 gallon gas water heater is far greater than the spread of the heat loss rate of 0.325 watts experienced by the water heater simulator. The preceding analysis shows that the standard deviation of 0.132 watts is a small variation of the mean loss rate of 8.75 watts. The spread of the test results of the seven capped, plugged and insulated tests of the water heater simulator was only 0.325 watts as compared to 78.37 watts with the 40 gallon gas water heater.

\subsection{CONCIUSIONS}

It is concluded that it is not possible to determine the effectiveness of heat traps by direct means when they are installed on gas water heaters. This is because the anticipated savings are well below the variability of the test results. This is the result of attempting to detect a change in heat loss rate of about 28 watts in a total heat 
loss rate of about 360 watts. In addition, tests have shown that the spread of the heat loss rate was about 78 watts when tested seven times on a gas water heater. It is surmised that because of electric water heater's generally lower standby losses the error effect would not be as great, nevertheless, it is also concluded that the effectiveness of heat traps when tested on electric water heaters can not be determined reliably when so installed and tested. It is further concluded that an indirect method of testing heat traps as described in this report, using a water heater simulator, is a prefered method of determining the effectiveness of heat traps.

The test results indicate that the heat trap tests conducted using the water heater simulator should be substantially more accurate than the same tests using the 40 gallon gas water heater.

When it is considered that the total heat loss rates that heat traps may save (with heat traps on both the hot water outlet and cold water inlet of a water heater) is about 28 watts [4] and that the spread of heat loss rates observed in seven tests of the 40 galion gas water heater (under the same test conditions) was 78.37 watts it is apparent that the effectiveness of heat traps can not be reliably determined by testing on gas water heaters.

\subsection{RECOMMENDATIONS}

It is recommended that the procedure for testing the effectiveness of heat traps follow the procedure described in this report using a water heater simulator of the type shown in Figures 4 and 5 .

It is also recommended that the heat trap credits ( $J h$ and $J c$ in the equations in paragraphs 4.5 .2 and 4.5 .4 ) of [4] be deleted. The rationale for this recommendation is that if the test procedures for the pipe hook-up to the test water heater as described in [4] are followed, then heat traps will be installed in those water heaters without integral heat traps. The test results will then allow a credit for heat traps so installed. In the case of water heaters with integral heat traps they will also be given credit in the test results. In either case the credit will be included in the results of the tests conducted and it is not appropriate to give further credit for heat traps. 


\section{ACKNOWLEDGEMENTS}

The author wishes to acknowledge the contributions of messers Irving Philmon and Robert A. Wise in the data collection, technical assistance, manuscript preparation and review of this report.

\section{REFERENCES}

1. SPC 115P, Second Working Draft, April, 1983, ASHRAE Standard; "Method of Testing for Rating Air Source Heat Pump Water Heaters", American Society of Heating, Refrigeration and Air-Conditioning Engineers.

2. Harris, James E., "Test Results on the Effectiveness of Heat Traps of Water Heaters", NBS, Letter Report to Department of Energy, May 1982

3. Nordstrum, Edwin A., Letter to Esher Kwelzer (NBS), August 10,1981

4. "Test Procedures for Water Heaters", Federal Register, Vol. 42, No.192, Tuesday, October 4, 1977, pp: 54110-54119

5. Pierson, Ryan; Innovative Features/Water Heaters, 4461124, Milestone Report: "Procedure for Evaluating the Efficiencies of Water Heaters With and Without Heat Traps", NBS, April 1977.

6. Galowin, I. S., Senior Engineer; at NBS, Center for Buiding Technology, Building Equipment Division, Personal Conversation. 
TABLE 4. UNITS CONVERSION TABLE: SI/INCH-POUND/SI

\begin{tabular}{|c|c|c|}
\hline TO CONVERT & MULTIPLY BY & TO OBTAIN \\
\hline $\begin{array}{l}\text { gpm } \\
\text { (Gallons/minute) }\end{array}$ & 0.06309 & $\begin{array}{l}\text { L/s } \\
\text { (Liters/second) }\end{array}$ \\
\hline $\begin{array}{l}\text { L/s } \\
\text { (Liters/second) }\end{array}$ & 15.85 & $\begin{array}{l}\text { gpm } \\
\text { (Gallons/minute) }\end{array}$ \\
\hline $\begin{array}{l}\mathrm{g} \\
\text { (Gallons) }\end{array}$ & 3.785 & $\begin{array}{l}\text { L } \\
\text { (Liters) }\end{array}$ \\
\hline $\begin{array}{l}\text { L } \\
\text { (Liters) }\end{array}$ & 0.2642 & $\begin{array}{l}g \\
\text { (Gallons) }\end{array}$ \\
\hline $\begin{array}{l}\text { in } \\
\text { (Inches) }\end{array}$ & 2.54 & $\begin{array}{l}\text { cm } \\
\text { (Centimeters) }\end{array}$ \\
\hline $\begin{array}{l}\text { cm } \\
\text { (Centimeters) }\end{array}$ & 0.3937 & $\begin{array}{l}\text { in } \\
\text { (Inches) }\end{array}$ \\
\hline $\begin{array}{l}\mathrm{ft} \\
(\mathrm{Feet})\end{array}$ & 0.3048 & (Meters) \\
\hline $\begin{array}{l}\mathrm{m} \\
\text { (Meters) }\end{array}$ & 3.281 & $\begin{array}{l}\mathrm{ft} \\
(\mathrm{Feet})\end{array}$ \\
\hline $\begin{array}{l}\text { BTU } \\
\text { (British Thermal Units }\end{array}$ & 1.055 & $\begin{array}{l}\mathrm{kJ} \\
\text { (kilojoules) }\end{array}$ \\
\hline $\begin{array}{l}\text { kJ } \\
\text { (kilojoules) }\end{array}$ & 0.9479 & $\begin{array}{l}\text { BTU } \\
\text { (British Thermal Units) }\end{array}$ \\
\hline
\end{tabular}

TEMPERATURE (T), CONVERSION EQUATIONS:

For Temperature Use:

${ }^{\circ} \mathrm{F}$ to ${ }^{\circ} \mathrm{C}:\left[(\mathrm{T}){ }^{\circ} \mathrm{F}-32^{\circ} \mathrm{F}\right](5 / 9)=(\mathrm{T}){ }^{\circ} \mathrm{C}$

${ }^{\circ} \mathrm{C}$ to ${ }^{\circ} \mathrm{F}:(\mathrm{T}){ }^{\circ} \mathrm{C}(9 / 5)+32^{\circ} \mathrm{F}=(\mathrm{T}){ }^{\circ} \mathrm{F}$

FOR TEMPERATURE DIFFERENTIALS OR TOLERENCES USE:
${ }^{\circ} \mathrm{F}$ to ${ }^{\circ} \mathrm{C}$ :
$(\mathrm{T}){ }^{\circ} \mathrm{F}(5 / 9)=(\mathrm{T}){ }^{\circ} \mathrm{C}$
${ }^{\circ} \mathrm{C}$ to ${ }^{\circ} \mathrm{F}$ :
$(\mathrm{T}){ }^{\circ} \mathrm{C}(9 / 5)=(\mathrm{T}){ }^{\circ} \mathrm{F}$ 
NBS-114A (REV. 2-AC)

U.S. DEPT. OF COMM

BIBLIOGRAPHIC DATA

SHEET (See in structions)

1. PUBLICATION OR

2. Performing Organ. Report Nof 3. Publication Date REPORT NO.

NBSIR $84-2851$

March 1984

4. TITLE AND SUBTITLE

TEST RESULTS AND A RECOMMENDED TEST PROCEDURE FOR HEAT TRAPS

5. $A \cup T H O R(S)$

James E. Harris

6. PERFORMING ORGANIZATION (If joint or other than NBS, see in structions)

7. Contract/Grant No.

NATIONAL BUREAU OF STANDARDS

OEPARTMENT OF COMMERCE

WASHINGTON, D.C. 20234

9. SPONSORING ORGANIZATION NAME AND COMPLETE ADDRESS (Street, City. State, ZIP)

United States Department of Energy

Washington, DC 20585

10. SUPPLEMENTARY NOTES

Document describes a computer program; SF-185, FIPS Software Summary, is attached.

11. ABSTRACT (A 200-word or less factual summary of most significant information. If document includes a significant bibliography or literature survey, mention it here)

A series of standby loss tests was conducted on a 40 gallon gas water heater to determine the standby losses and the variability of those losses. Tests were run with both inlet and outlet plugged and insulated to determine the jacket losses, then tests were conducted with bare and insulated, vertical copper pipe, with and without heat traps. It was determined that the variability of the heat losses was large enough to conclude that the possible heat loss reduction by the use of heat traps could not be accurately detected and therefore the effectiveness of heat traps could not be accurately tested on gas water heaters. A recommended test procedure for heat traps was developed using a water heater simulator and then a number of tests were conducted with four different heat traps, in a variety of pipe sizes and material, bare and insulated, in vertical and horizontal orientations. It was recommended that the water heater simulator be used for any heat trap testing. It was also recommended that the heat trap credits currently given in the DOE water heater test procedure be dropped since any benefit of heat traps will be shown by the test results.

12. KEY WORDS (Six to twelve entries; alphabetical order; capitalize only proper names; and separate key words by semicolons) appliances; energy; heat traps; test procedures; testing; water heaters

13. AVAILABILITY

XX Unlimited

$\square$ For Official Distribution. Do Not Release to NTIS

$\square$ Order From Superintendent of Documents, U.S. Government Printing Office, Washington, D.C. 20402.

14. NO. OF

PRINTED PAGES

29

15. Price

XX Order From National Technical Information Service (NTIS), Springfield, VA. 2216I

$\$ 8.50$ 

